Article

\title{
Qualitative Analysis of Satisfying and Dissatisfying Factors in a University-Industry Cooperation Programme
}

\author{
Jian Ming Luo ${ }^{1}$ and Chi Fung Lam ${ }^{2, *}$ \\ 1 Faculty of International Tourism and Management, City University of Macau, Taipa, Macau, China; \\ kennyluo@cityu.mo or kenny.luo@connect.polyu.hk \\ 2 Department of Finance, The Chinese University of Hong Kong, Hong Kong, China \\ * Correspondence: kelvinlam@cuhk.edu.hk
}

Received: 4 February 2019; Accepted: 3 March 2019; Published: 13 March 2019

\begin{abstract}
Using qualitative semistructured interviews, this study aims to analyse the satisfying and dissatisfying factors in a university-industry cooperation programme. Work experience, monetary benefit, HR policies, language and time are important factors determining the satisfaction and dissatisfaction of students towards a university-industry cooperation programme. Results help in evaluating and identifying the sustainability of a programme. Marketing practitioners can consider the results in designing corresponding marketing strategies, and HR managers and programme coordinators can formulate guidelines for future improvements of related programmes.
\end{abstract}

Keywords: university-industry cooperation; sustainability; satisfaction; Macau

\section{Introduction}

Learning is a continuous process, and experience can help gain knowledge. The learning cycle consists of experience, reflection, conceptualisation and experimentation [1]. To meet the complex and constantly changing working environment, education institutions are required to train sufficient and adequate skilled graduates [2]. Therefore, educational institutions must help students connect classroom knowledge with application in practice [3]. A way to address this problem is to partner with corporations [4]. Cooperative education and internship are the two most commonly used methods to enhance student knowledge about real practice [5,6]. During internships, students are required to work in usual offices and perform job duties similar to full-time employees. Hence, students can do similar work and gain experience in an organisation [7].

The importance of the link between the hospitality industry and education has been identified in various studies [6-10]. Kakalauskas et al. [11] suggested that different resources, techniques and systems should be utilised to ensure the sustainable development of a university-industry cooperation programme. Given that one of the objectives of an education institution is to provide trained graduates to support professionals, a close connection between education institutions and hospitality is necessary [12]. The close connection will allow education institutions to identify industry needs [13]. In addition, academic researchers will be able to work with the industry and to develop and enhance the relationship between the academe and business [14,15]. Internships have proven effective in integrating education and work experience and assisting students to transition from a classroom to an actual workplace [16].

The Bachelor of International Hospitality and Tourism Management at the City University of Macau is a university-industry cooperation programme that provides students actual experiences in hospitality institutions, sponsorships and allowance simultaneously [17]. Student satisfaction is important to universities [18]. To effectively utilise university resources, tracking student satisfaction is important [19]. Hence, to create a successful and sustainable university-industry 
cooperation programme, the university would need to develop its programme and courses according to market needs. Therefore, researchers must identify factors that affect student satisfaction [20]. Such collaborations have attracted researchers [21]. Improving programme management requires the examination of the effectiveness of programmes by means of discovering the satisfaction and dissatisfaction factors of students. To the best our knowledge, no previous studies have investigated this issue in a four-year university-industry cooperation programme.

Although the purpose of this study is to identify the satisfaction and dissatisfaction factors of a university-industry cooperation programme, this study further identifies the strengths and weaknesses of a programme. Hence, this study provides insights for educators and practitioners about the most satisfactory way to integrate commercial practices and student learning opportunities and to develop and sustain university-industry cooperation programmes.

\section{Literature Review}

\subsection{University-Industry Cooperation Programme in Macau}

Cooperative education is an important educational strategy in higher education programs [22]. Cooperative education program are typically degree-level programs that combine classroom-based instruction with one or more periods of relevant experiential learning in authentic work settings [23]. Obtaining work experience in an integrated program of higher education becomes increasingly popular. This led to the development of significant numbers of educational programs that incorporate some experience in a relevant workplace [24]. Research suggests that cooperative education programs are successful in placements, gain confidence in their ability to work, and lead to more satisfying and well-paid careers $[25,26]$. Through cooperative education programs, students are not only able to engage more readily with the world of work, but they also engage with themselves and the wider environment differently [27].

Given the enormous growth Macau experienced during the last decade, Macau has now become a world-class tourism destination [28,29]. The Macau government has tried to develop Macau through education and cultivate talents for the development of Macau using different methods [30]. One of the reasons why local companies in Macau participate in a university-industry cooperation programme is to resolve labour shortage, especially in the tourism and hospitality industry [17]. In 2013, the City University of Macau and Sheraton Macau Cotai jointly developed the 'Sheraton Sponsorship and Talent Development Project', which is a university-industry cooperation programme. The two parties put high expectations on the programme, which exposes students to different positions in Sheraton Macau Cotai to accumulate work experience [31]. A dedicated officer schedules the work and school time to reduce work and school time conflicts. Participants are considered full-time workers and students. To an extent, this programme is different. Firstly, the duration of this programme is longer (four years) than usual internship programmes. Secondly, students enrolled in this programme must balance their personal and work lives on top of their usual school life. Third, this programme is innovative and experimental in nature [17]. To ensure the successful completion of students in this programme, Sheraton Macau fully cooperates with the City University of Macau. The management of Sheraton Macau believes that this programme will provide students, especially those who are studying hospitality and tourism, valuable opportunities to experience work in practical settings. Therefore, they expect students to remain at Sheraton Macau after graduation More than 250 students are enrolled in this programme.

\subsection{Factors Influencing Student Satisfaction and Dissatisfaction}

Many universities, which notice the importance of internships, provide voluntary or compulsory (as a requirement of graduation) internship programmes. These internship programmes enhance the job placements of students after graduation and allow universities to examine the relevance and appropriateness of their curriculum [32]. Previous research corroborated that positive word-of-mouth 
amongst students increases the number of new applications and enrolment [18,33]. Student satisfaction positively affects fundraising and student motivation [34].

Student satisfaction is defined as a student's subjective evaluation of the outcomes and experiences resulting from education [31]. According to Lam and Ching [35], student satisfaction is derived from the differences between their expectations and perceptions of internship experiences. Expectation is the student's ex ante feeling, whilst perception is the student's ex-post feeling. The difference between the two is defined as the student's satisfaction level. Investigating student satisfaction can detect problems to improve the design and execution of internship programmes. Previous studies identified several important and influential aspects and dimensions of student satisfaction. For instance, prior industry experience [36], job characteristics [37], supervisory support; supervisor knowledge [35], salary level [38] and personal factors, such as gender, nationality and personality [39], may partly explain the inconsistency in the results produced by previous investigations [16].

Whilst internship creates satisfaction, dissatisfaction can occur due to actual industrial work experience, especially when the actual experience does not match the expectation. Students expect internships to improve their professional and personal skills [40]. Previous research affirmed that expectation usually develops before internship and is affected by academic theorising, information sources, past industry experience, level of training provided at university and the degree of work readiness of the student $[10,16,38,41]$.

\section{Methods}

This study aimed to explore the effect of student satisfaction factors in a university-industry programme. Adopting an interpretive approach is important to understand the feeling of readiness, whereby students explore the narrative of their experiences [42]. This study used a qualitative approach along with an in-depth semistructured interview to collect and analyse data. This approach allowed researchers to investigate the views and experiences of the students [43]. In qualitative sampling, representation and scale are not the most important consideration [44]. The most important consideration is the precision and rigour of the research, which is defined as the ability to describe the salient characteristics [45]. Therefore, sample selection, i.e., background, grade and gender, is very important to ensure that the sample is diverse enough [42]. Age is not a criterion of sample selection because most students were under 25 years of age. Students in their first to final (4) years of study were included in the sample.

Researchers conducted face-to-face and one-on-one semistructured interviews with students at the university or place of convenience (i.e., library and canteen) from June to July 2018. Each interview was approximately $30 \mathrm{~min}$. The interview questions were based on research objectives: (1) What are the most satisfying aspects of this programme, why? (2) What are the most dissatisfying aspects of this programme, why? (3) Any suggestions for improvements in this program? Constant comparison method was used to analyse data. According to Glaser and Strauss [46], this method systematically records, codes and analyses data. To capture every aspect, verbal or nonverbal, of the interviewees, researchers might ask questions to clarify during, before or after the interviews. Data saturation was reached after 32 interviews. The interviews were recorded, transcribed and entered into NVIVO 11.0 for content analysis.

\section{Findings and Discussion}

\subsection{Characteristics of Interviewees}

A qualitative approach along with personal interviews was used to discover satisfying and dissatisfying factors in the university-industry programme. Forty-four percent of the respondents are male, and the $58 \%$ are female. On the basis of the year of study, $31 \%$ were in year $4,25 \%$ in year $2,22 \%$ in year 3 and $22 \%$ were in year 1 . Table 1 presents the demographic information of the respondents and their characteristics. 
Table 1. Profile of respondents.

\begin{tabular}{cccccc}
\hline Gender & Year 1 & Year 2 & Year 3 & Year 4 & Total \\
\hline Male & 3 & 3 & 4 & 4 & 14 \\
Female & 4 & 4 & 4 & 6 & 18 \\
Total & 7 & 7 & 8 & 10 & 32 \\
\hline \multicolumn{7}{c}{ 'No' means the number of interviewees. }
\end{tabular}

\subsection{Student Satisfaction Factors}

Table 2 lists the main satisfaction factors of the university-industry cooperation programme and their corresponding subthemes. The five factors included working experience, monetary benefit, human resource (HR) policy, language and time. Most interviewees said that experience was one of the most important factors in this cooperation programme. This cooperation programme allowed them to obtain industry experience and enhanced their social network (Interviewee 5). Moreover, students could enrol in different departments, such as front desk, housekeeping and marketing. Therefore, students obtained sufficient experience in different positions and could make better career choices in the future (Interviewee 10). The second most frequently mentioned factor is economic. Students appreciated the elimination of tuition fees. In addition, the cooperation programme provided basic salary, which improved their living standard (Interviewee 20). The third most frequently mentioned factor was time. This programme saved their learning acquisition and working time. Normally, to obtain an undergraduate degree, students would need to spend four years. In addition, they would need to spend another four years to obtain industry experience. However, this programme can be finished within four years (Interviewee 1). The programme chose the elective courses for all students, which reduced the amount of time to consider which electives to take (Interviewee 22). The fourth most frequently mentioned factor was HR policy. When students joined this programme, they obtained many employee benefits and the opportunity for promotion (Interviewee 20). The least frequently mentioned factor is language. Students obtained the opportunity to practice their foreign language skills.

Table 2. Results of content analysis on satisfying factors.

\begin{tabular}{cccccc}
\hline Themes & Subthemes & Year 1 & Year 2 & Year 3 & Year 4 \\
\hline \multirow{2}{*}{ Working experience } & Industry experience enhanced social network & 7 & 5 & 8 & 9 \\
& Job rotation experience & 5 & 3 & 2 & 5 \\
\hline \multirow{2}{*}{ Monetary benefit } & Tuition is waived & 5 & 4 & 5 & 6 \\
& Internship salary & 2 & 4 & 3 & 5 \\
\hline \multirow{2}{*}{ HR policy } & Employee benefit & 3 & 1 & 0 & 1 \\
& Promotion opportunity & 0 & 0 & 1 & 2 \\
\hline Language & Foreign language practice & 0 & 0 & 1 & 1 \\
\hline Time & Education process speed up & 4 & 5 & 5 & 7 \\
\hline
\end{tabular}

'No.' means the number of times being mentioned by different interviewees.

\subsection{Student Dissatisfaction Factors}

Table 3 lists the main dissatisfying factors of the university-industry cooperation programme and their corresponding subthemes. The four factors were management, monetary benefit, HR policy and time. The most frequently mentioned factor is management. The job rotation was too fast: before students became fully familiar with the department, they were already rotated to other departments (Interviewee 8). In addition, students were not allowed to select the departments they were interested in (Interviewee 19). Supervisors in the companies did not fully appreciate students who were working and studying simultaneously. Supervisors would request overtime work although students were expected to attend classes. The second most frequently mentioned factor was time. As running a hotel is a 24 -h business, employees must work in different shifts, i.e., midnight shifts. After students 
worked during these shifts, they were expected to come to class immediately (Interviewee 16). The third most frequently mentioned factor was monetary benefit. Students claimed that they could earn higher wages by working part-time than in the internship. Therefore, they were unhappy with the low salary offered by the company (Interviewee 12). The least frequently mentioned factor was HR policy. Students were dissatisfied at the difference between full-time employee and intern benefits (Interviewee 14) and the limited amount of employee benefits (Interviewee 9).

Table 3. Results of content analysis on dissatisfying factors.

\begin{tabular}{cccccc}
\hline Themes & Subthemes & Year 1 & Year 2 & Year 3 & Year 4 \\
\hline \multirow{3}{*}{ Management } & Rotation arrangement is too fast & 5 & 2 & 2 & 3 \\
& Supervisory support is weak & 2 & 3 & 4 & 3 \\
& Job preference mismatch & 3 & 4 & 5 & 6 \\
\hline \multirow{2}{*}{ Monetary benefit } & Low salary & 6 & 7 & 5 & 7 \\
\hline \multirow{2}{*}{ HR Policy } & Unfair benefit arrangement & 3 & 5 & 4 & 5 \\
& Limited employee benefit & 1 & 0 & 1 & 2 \\
\hline Time & Limited rest time & 4 & 6 & 8 & 8 \\
\hline \multicolumn{2}{c}{ 'No.' means the number of times being mentioned by different interviewees. }
\end{tabular}

\section{Implication and Suggestions}

This study discovered several factors of the cooperation programme that affected student satisfaction. On the basis of qualitative interviews with students, five main factors affected student satisfaction, and four main factors affected student dissatisfaction. Several of the factors discovered by this study are consistent with previous research. For instance, working experience was found in Lee, Chen, Hung and Chen [36]; salary was found in Chen, Ku, Shyr, Chen and Chou [38]; and supervisory support was found in Lam and Ching [26]. Despite the consistency, small differences were observed. This study identified tuition fee reduction as a subfactor that affected student satisfaction. Furthermore, this study identified job rotation as a subfactor that affected student satisfaction. This result sharply contrasted with the results of previous studies. Most of the cooperation programmes in previous studies are short-term internship programmes, whilst the duration of the cooperation programme in this study is four years. Students can fully appreciate the benefit of obtaining different experiences from different departments and extend their social network. However, this subfactor created dissatisfaction as well. Whilst some students said that the job rotation was too fast, other students said they could not choose the department on the basis of their preference.

In addition, special features were discovered by this study. For instance, this study found time as an important factor that affected student satisfaction and dissatisfaction. On the one hand, the cooperation programme can effectively reduce the amount of time students need to prepare for future jobs whilst obtaining a university degree. On the other hand, several students claimed they did not have enough rest time. Students were assigned to different departments on different schedules. Given the labour shortage in Macau [17], supervisors or managers in the companies would request students to work overtime. This practice easily affects the study and rest time of students. This factor was the main reason why students believed supervisors were unsupportive.

This study makes several important contributions. Firstly, this study confirms factors that affect student satisfaction and dissatisfaction toward a cooperation programme. This study confirms work experience, monetary benefit, HR policy and language as the satisfaction factors. Furthermore, student satisfaction is affected by time. On the one hand, the cooperation programme can effectively reduce the amount of time spent on internships and university degree. On the other hand, heavy workload, no matter from universities or companies, and tight schedules reduce students' rest time.

Second, from the company and cooperation programme perspective, this study discovered that more coordination is needed between the cooperation programme and the corresponding internship companies because students' rest time directly affected their work and academic performance. In addition, this study identified work experience and tuition fee reduction as the most important 
factors that affected student satisfaction. Therefore, these two factors can be used to promote university-industry cooperation programme sustainability to the public.

Finally, from the university perspective, when the university is recruiting students to this programme, the university should make applicants understand the uniqueness of this programme. In addition, the programme must prepare applicants to be ready physically and psychologically. Students should be made to anticipate working and studying simultaneously; hence, they should not expect the same number of holidays as other students have.

In conclusion, this study confirms the factors influencing student satisfaction in a university-industry cooperation programme. The industry experience enhanced the social network and job rotation experience of the students. Moreover, the advantages further included waived tuition, internship salary, employee benefits, promotion opportunity and foreign language practice. These factors sped up education processes and positively affected student satisfaction. Meanwhile, factors that had negative impacts on student satisfaction included fast rotation arrangements, unsupportive supervisors, mismatched job preferences, low salary, unfair benefits, limited employee benefit and shortened rest time.

\section{Research Limitations and Future Research}

Several limitations of this study require further investigations. Firstly, this study obtained the sample from one university-industry cooperation programme in Macau. The result is limited to general. In the future, researchers may conduct a similar study on another country or programme to build on these findings. Many programme stakeholders, such as HR managers, programme coordinators and parents, were not included in this study. Future research could increase the sample size and diversity of the respondents to conduct a more in-depth analysis of the satisfaction factors. Moreover, this study is qualitative. Quantitative methods, such as exploratory and confirmatory factor analyses, can be used in the future to obtain more fruitful results.

Author Contributions: The outline of the study was led by J.M.L. J.M.L. and C.F.L. designed and completed the paper.

Funding: This project was partly supported by a research grant funded by the Macau Foundation.

Acknowledgments: The authors wish to acknowledge the help of Kun Wang, Shu Juan Wan and Ya Fei Lan from the City University of Macau.

Conflicts of Interest: The authors declare no conflict of interest.

\section{References}

1. Kolb, D. Experiential Learning as the Science of Learning and Development; Printice-Hall: Englewood Cliffs, NJ, USA, 1984.

2. King, Z. New or traditional careers? A study of UK graduates' preferences. Hum. Resour. Manag. J. 2003, 13, 5-26. [CrossRef]

3. Meredith, S.; Burkle, M. Building bridges between university and industry: Theory and practice. Educ. Train. 2008, 50, 199-215. [CrossRef]

4. Salimova, T.; Vatolkina, N.; Makolov, V. Strategic Partnership: Potential for Ensuring the University Sustainable Development. Qual. Innov. Prosperity 2014, 18, 107-124. [CrossRef]

5. Gault, J.; Redington, J.; Schlager, T. Undergraduate business internships and career success: Are they related? J. Mark. Educ. 2000, 22, 45-53. [CrossRef]

6. Khalil, O.E. Students' experiences with the business internship program at Kuwait University. Int. J. Manag. Educ. 2015, 13, 202-217. [CrossRef]

7. Rothman, M. Lessons learned: Advice to employers from interns. J. Educ. Bus. 2007, 82, 140-144. [CrossRef]

8. Barrows, C.W.; Walsh, J. "Bridging the gap" between hospitality management programmes and the private club industry. Int. J. Contemp. Hosp. Manag. 2002, 14, 120-127. [CrossRef]

9. Littlejohn, D.; Watson, S. Developing graduate managers for hospitality and tourism. Int. J. Contemp. Hosp. Manag. 2004, 16, 408-414. [CrossRef] 
10. Zopiatis, A. Hospitality internships in Cyprus: A genuine academic experience or a continuing frustration? Int. J. Contemp. Hosp. Manag. 2007, 19, 65-77. [CrossRef]

11. Kaklauskas, A.; Banaitis, A.; Ferreira, F.A.; Ferreira, J.J.; Amaratunga, D.; Lepkova, N.; Banaitienė, N. An Evaluation System for University-Industry Partnership Sustainability: Enhancing Options for Entrepreneurial Universities. Sustainability 2018, 10, 119. [CrossRef]

12. Zopiatis, A.; Constanti, P. "And never the twain shall meet" Investigating the hospitality industry-education relationship in Cyprus. Educ. Train. 2007, 49, 391-407. [CrossRef]

13. Smith, G.; Cooper, C. Competitive approaches to tourism and hospitality curriculum design. J. Travel Res. 2000, 39, 90-95. [CrossRef]

14. Pauline, G.; Pauline, J.S. Teaching sport sponsorship activation through a client-based experiential learning project. Sport Manag. Educ. J. 2008, 2, 19-37. [CrossRef]

15. Brown, C.; Willett, J.; Goldfine, R.; Goldfine, B. Sport management internships: Recommendations for improving upon experiential learning. J. Hosp. Leis. Sport Tour. Educ. 2018, 22, 75-81. [CrossRef]

16. Farmaki, A. Tourism and hospitality internships: A prologue to career intentions? J. Hosp. Leis. Sport Tour. Educ. 2018, 23, 50-58. [CrossRef]

17. Luo, J.M.; Chau, K.Y.; Lam, C.F.; Huang, G.Q.; Kou, I.T. Attitudes of Undergraduate Students from University-Industry Partnership for Sustainable Development: A Case Study in Macau. Sustainability 2018, 10, 1378. [CrossRef]

18. Alemu, A.M.; Cordier, J. Factors influencing international students satisfaction in Korean universities. Int. J. Educ. Dev. 2017, 57, 54-64. [CrossRef]

19. Thiuri, P. International Student Satisfaction with Student Services at the Rochester Institute of Technology; ProQuest LLC: Ann Arbor, MI, USA, 2011.

20. Fong, L.H.N.; Luk, C.; Law, R. How do hotel and tourism students select internship employers? A segmentation approach. J. Hosp. Leis. Sport Tour. Educ. 2014, 15, 68-79. [CrossRef]

21. Perkmann, M.; King, Z.; Pavelin, S. Engaging excellence? Effects of faculty quality on university engagement with industry. Res. Policy 2011, 40, 539-552. [CrossRef]

22. Dearing, R. Report of the Committee of Inquiry into Higher Education; Her Majesty's Stationery Office: London, UK, 1997.

23. Todd, A.M.; Lay, M. Cooperative and work-integrated education in engineering. In International Handbook for Cooperative and Work integrated Education: International Perspectives of Theory, Research and Practice; University of Waikato: Hamilton, New Zealand, 2011; pp. 111-121.

24. Sovilla, E.S.; Varty, J.W. Cooperative and work-integrated education in the US, past and present: Some lessons learned. In International Handbook for Cooperative and Work-Integrated Education, 2nd ed.; World Association for Cooperative Education: Lowell, MA, USA, 2011; pp. 3-15.

25. Bates, M. Work-integrated curricula in university programs. High. Educ. Res. Dev. 2008, $27,305-317$. [CrossRef]

26. Green, J.P. The impact of a work placement or internship year on student final year performance: An empirical study. Int. J. Manag. Educ. 2011, 9, 49-57. [CrossRef]

27. Allen, J.; Van der Velden, R. Transitions from higher education to work. High. Educ. Dna. 2007, 17, 55-78.

28. Luo, J.M. A measurement scale of corporate social responsibility in gambling industry. J. Qual. Assur. Hosp. Tour. 2018, 19, 460-475. [CrossRef]

29. Luo, J.M.; Lam, C.F.; Fan, D.X. The development of measurement scale for entertainment tourism experience: A case study in Macau. Curr. Issues Tour. 2018, 1-15. [CrossRef]

30. Government Information Bureau. Information. 2017. Available online: http://www.gcs.gov.mo/files/ factsheet/Education_EN.pdf (accessed on 1 January 2019).

31. City University of Macau. The "Sheraton Professional Development Scheme" of City U Feeds the Industry with Professionals. 2015. Available online: http://www.cityu.edu.mo/en/the-sheraton-professionaldevelopment-scheme-of-city-u-feeds-the-industry-with-professionals / (accessed on 1 January 2019).

32. Ross, C.M.; Beggs, B.A. Campus recreational sports internships: A comparison of student and employer perspectives. Recreat. Sports J. 2007, 31, 3-13. [CrossRef]

33. Helgesen, Ø.; Nesset, E. What accounts for students' loyalty? Some field study evidence. Int. J. Educ. Manag. 2007, 21, 126-143. 
34. Elliott, K.M.; Shin, D. Student satisfaction: An alternative approach to assessing this important concept. J. High. Educ. Policy Manag. 2002, 24, 197-209. [CrossRef]

35. Lam, T.; Ching, L. An exploratory study of an internship program: The case of Hong Kong students. Int. J. Hosp. Manag. 2007, 26, 336-351. [CrossRef]

36. Lee, D.C.; Chen, C.F.; Hung, L.M.; Chen, C.C. Effects of labor conditions, socialization and personality upon student interns working willingness in hospitality industry. Afr. J. Bus. Manag. 2011, 5, 11813-11825.

37. Varshney, S.; Mishra, N. Students perspective towards internship at higher education institutes in Oman. Int. J. Bus. Manag. 2014, 2, 109.

38. Chen, F.C.; Ku, E.; Shyr, Y.H.; Chen, F.H.; Chou, S.S. Job demand, emotional awareness, and job satisfaction in internships: The moderating effect of social support. Soc. Behav. Personal. 2009, 37, 1429-1440. [CrossRef]

39. Chen, T.L.; Shen, C.C. Today's intern, tomorrow's practitioner?-The influence of internship programmes on students' career development in the Hospitality Industry. J. Hosp. Leis. Sport Tour. Educ. 2012, 11, $29-40$. [CrossRef]

40. Jaradat, G.M. Internship training in computer science: Exploring student satisfaction levels. Eval. Prog. Plan. 2017, 63, 109-115. [CrossRef]

41. Singh, A.; Dutta, K. Hospitality internship placements: Analysis for United Kingdom and India. J. Serv. Res. 2010, 10, 85-99.

42. Bell, E.; Bryman, A.; Harley, B. Business Research Methods; Oxford University Press: Oxford, UK, 2018.

43. Bryman, A. Social Research Methods; Oxford University Press: Oxford, UK, 2016.

44. Holloway, I.; Galvin, K. Qualitative Research in Nursing and Healthcare; John Wiley \& Sons: West Sussex, UK, 2016.

45. Ritchie, J.; Lewis, J.; Nicholls, C.M.; Ormston, R. Qualitative Research Practice: A Guide for Social Science Students and Researchers; Sage: London, UK, 2014.

46. Glaser, B.; Strauss, A. The Discovery of Grounded Theory: Strategies for Qualitative Research; Routledge: Abingdon, UK, 2017.

(C) 2019 by the authors. Licensee MDPI, Basel, Switzerland. This article is an open access article distributed under the terms and conditions of the Creative Commons Attribution (CC BY) license (http:/ / creativecommons.org/licenses/by/4.0/). 